Island Studies Journal, Vol. 11, No. 1, 2016, pp. 193-208

\title{
Good work? Scottish cultural workers' narratives about working and living on islands
}

\author{
Lynda Harling Stalker \\ St. Francis Xavier University \\ Antigonish NS, Canada \\ lharling@stfx.ca
}

and

Kathryn A. Burnett

University of the West of Scotland

U.K.

kathryn.burnett@uws.ac.uk

\begin{abstract}
This paper sets out to ask how cultural workers on Scottish islands come to narrate their work and everyday life experiences. We ask this question in the context of two dominant doctrines that can influence whether or not these experiences are "good or bad." The first doctrine describes attitudes toward creativity with reference to current discussions around cultural work and the idea of "creative." The second doctrine highlights conceptions of islands as unique places with pastoral characteristics that need to be fostered and promoted. It is our contention that island cultural workers must continuously negotiate with these two frameworks in order to successfully achieve good work. If the negotiation is fraught with difficulties, the cultural worker will ultimately leave either this form of work or the island. For the purpose of this paper we focus on the narratives of two cultural workers located on two different Scottish islands to highlight the ways their particular narratives engage with the doctrines of creativity and islandness.
\end{abstract}

Keywords: creative industries, cultural workers, islands, Scotland, working narratives

(C) 2016 - Institute of Island Studies, University of Prince Edward Island, Canada

\section{Introduction}

In recent years, governments and policymakers have been looking to stem the tide of outmigration and depopulation of rural and remote areas. Small islands are included in this endeavour, not least in Scotland. The usual tropes are called upon to encourage people to stay, if not relocate to these islands: beautiful landscapes, slower pace of life, know your neighbour, good place to raise children, and so on (HallAitken, 2007). Economic development boards and local authorities produce promotional material including film, available widely on digital platforms like YouTube, to supply visuals to augment these messages (e.g. Scottish Development International TalentScotland Film, 2009). The relative remoteness is seen as an asset as opposed to a liability. Property is often more affordable and you are removed from the "rat race" of the city (Jedrej and Nuttall, 1996). Islands are good places to not only live but work (Parr, 2013; Millan, 2015). Cultural work seems like a natural fit for working on islands. Islands are seen as having unique cultural features that are ripe to be mined and marketed 
(Royle, 2008). Language, food, art and crafts are all commodities that one can create / make and present to a waiting market, usually tourist. The exclusive focus on the positive aspects of island life and cultural work as symbiotic seems to be taken for granted as a desirable line of development and promotion. This focus can produce a doctrine mentality that can obscure potentially negative realities.

Doctrines, by their very nature, are political actions that are often abstract and inflexible (Williams, 1976/2015). Frequently they can be seen as undesirable or even quite absurd. The cultural workers in this study have arguably two dominant doctrines to contend with: the doctrine of creativity and the doctrine of islands. These two have a somewhat dichotomous dynamic, where on the one hand they are seen as seemingly positive while on the other the aura of positivity can mask tensions that can prohibit good work experience. This paper sets out to situate cultural workers' narratives in the context of these doctrines and the negotiation that the workers must do in order to be successful both as a cultural worker and an islander. In order to do this, we have decided to focus on the narratives provided by Helen and Jennifer, two cultural workers living on two different Scottish islands. 'These two women's narratives highlight the continuous negotiation one must make in order to make sense of work and island experiences.

\section{Doctrines of creativity}

The doctrine of creativity, as Hesmondhalgh and Baker (2010) point out, is an inflexible position whereby creativity is seen exclusively in a positive light. It is not to argue that creativity is bad. As Williams says, "No word in English carries a more consistently positive reference than 'creative,' and obviously we should be glad of this, when we think of the values it seeks to express and the activities it offers to describe" (1961/2001, p. 19). To be creative carries with it a unique sense of how things are made, with particular attention being paid to the values of innovation and originality (Williams, 1976/2015). Over the period of the word's etymology, creativity has been held up as this exceptional activity that only a few do, mainly "artists." While Williams takes issue with the idea of creativity being set aside for a seemingly privileged few, he does point out that the idea of creative is becoming so ubiquitous that it is becoming almost meaningless and useless.

Toynbee (2013, p. 85) argues that the cult of the artist, the "free-ranging genius," has been ongoing for centuries. It is that the artist does work that is special and is thereby allowed the autonomy and freedom to be creative in ways that other workers do not enjoy. This claim to specialness comes from an argument based on aesthetics and one based on resistance to industrialization (such as those made by the Romantics). Williams argues that this specialness, as mediated through the privilege of autonomy, carries positive and negative interpretations. Toynbee argues that what Williams is arguing is that the positive can be seen as acts of resistance to modernity; the negative can be seen as acts of retrenchment where the cultural workers remove themselves from the everyday social environment. ${ }^{2}$ Becker (1983) and Bourdieu (1990) both attack this specialist thesis, as cultural and creative work are entirely social actions that deal with the same concerns that other workers face (i.e. power). When aesthetics is removed, it is then questionable whether specialness exists (Toynbee, 2013).

\footnotetext{
${ }^{1}$ Pseudonyms are used to maintain confidentiality. Helen and Jennifer are part of our larger narrative study of cultural workers living and working on Scottish islands.

${ }^{2}$ This is reminiscent of discussions on islanders' reactions to change. E.g., Byron (2003) on Newfoundland.
} 
The over use of creative in the last couple of decades or so to describe a number of occupations has come to lend credence to Williams' point. With Richard Florida's (2002) use of the creative to examine work and the success of cities, creative is applied to everything from musicians, to architects, to scientific research and development lab workers. These are all positioned whereby it can certainly be argued that creativity is part of their work; but: is the prime objective "the process of making a meaning active, by communicating an organized experience to others" (Williams, 1961/2001, p. 49)? By applying the label creative to this range of occupation, the word becomes somewhat classist / elitist. If we follow through, creativity can only happen among these occupations which require substantial amounts of social and cultural capital. Florida (2002) unapologetically calls for the creative class to rise up and grab the power they already seemingly have. Governments and policymakers have come to embrace an economic model that was politically savvy and financially astute as a growth policy in some regard not least in Scotland (Bonnar, 2014; Matarasso, 1996). How could anyone question the importance of creativity and culture? Numerous reports, policies and initiatives flowed from the 1990s onward, not least in the UK (Myerscough, 1988; Mulholland, 2008) and indeed Scotland (MacKay Consultants and McGrath, 1991; Myerscough, 1995; Danson and Burnett, 2014). By the early 2000s culture was edged from much policymaking vocabulary and replaced with creative; a more palatable, and even a "blander" term yet arguably a term that lent itself more readily to mapping and measurement (Bonnar, 2014; Hesmondhalgh \& Baker 2010, p. 4). It was championed as a tool for development in regions and areas traditionally vulnerable with fragile growth economies yet rich in cultural resource and heritage such as Scotland's islands.

In the face of the contemporary creative economy policies, David Hesmondhalgh and Susan Baker (2011) pose the question: can cultural work be good work? They come to define good work as having "decent pay, hours and safety; autonomy; interest and involvement; sociality; esteem and self-esteem; self-realisation; work-life balance; security" (p. 17). This question has been taken up by many in the field to see whether or not good work can be had in the cultural industries (Ashton \& Noonan, 2013; Banks, Gill \& Taylor, 2013; Luckman, 2012, 2015; McRobbie, 2016). Many have questioned the possibility, including Hesmondhalgh and Baker (2010) themselves, citing the perpetual problems cultural workers face: precariousness, inequalities, assumed life-work balance, and an accelerated invasion into workers' private lives (Banks et al., 2013). Interestingly the 'lived realities' of remote, rural island living in Scotland include invasions of privacy, challenging employment markets including both seasonal labour and low-wages, and opportunities afforded by cultural distinctiveness and remoteness often result in both good and bad embodied experiences. Others have shown how cultural workers can experience proletarianization, despite being self-employed (Harling Stalker, 2009a). Despite this there are still 3,350 craft making businesses in Scotland alone, accounting for $£ 70$ million in annual income. Our research will add to the debates around work experiences of cultural workers.

\section{Doctrine of islands}

The doctrine of islands is often presented as either places to escape to or to escape from. As Baldacchino demonstrates, "islands have occupied such a powerful place in modern Western imagination that they lend themselves to sophisticated fantasy and mythology. Paradise, but also Gulags, are generally islands" (2005, pp. 247-248). The consequence of this is that islands 
are often places you either want to get to or get away from. Governments have used these to make life altering decisions for islands. Whether it is the iconic case of St. Kilda (Spring, 1990; Steel, 1975), or more recently Scotland's islands as re-energised places of enterprise and sustainability success as 'good places to live and work' (see Russell, 2013) the doctrine of islands continues to operate in this dichotomous manner.

Furthermore, remote islands, as glocalization has taken firm root, are increasingly positioned as entrepreneurial spaces that arguably offer 'good' sustainable models of practice for both cultural and natural heritage resource (Kelman, 2007). The implications for what is consequently defined as 'good island' work as enterprise and as 'sustaining' are in turn being reconfigured over time and space, as increasingly complex power configurations as to who or what lays claim to Scotland's island cultural and natural resources. Research examines, for example, how this is being done through government policy and the personalisation of social practices, spaces and collective resource (Danson and Burnett, 2014), and indeed on the complex 'hypocrisy' of island vulnerability and sustainability debates more globally (Baldacchino and Kelman, 2014).

Small islands have rhetorically, if not mythically (Baldacchino, 2013), been envisioned as pastoral places of escape. Pastoral comes to mean "removal from worldly affairs" (Adamson, 2007, p. 104), both spatially and temporally. The earliest use of the pastoral sentiment was in poetry, where the rural place is continually slipping away in the tides of change. There is a dialectical realization that the pastoral is a symbolic ideal that we are conscious of. It is about our inability to deal with cultural realities and looking for ways of escaping them. As William Empson (cited in Adamson, 2007) said, it is "putting the complex into the simple." Pastoral literature came to be an implied comparison between ambition, limited horizons and modest strengths. This sounds very much like the way islands come to be represented. Film, for example, targeted by tourist bureaus to promote the area to tourists or business bureaus hoping to attract investment, will often position the island in the realm of a rural idyll. This construction, however, is subject to deep histories of spatial and cultural inequities, and akin to Urry (1990), what we might term the 'island gaze.' The discussion Glenn Adamson (2007) has about summer craft schools is very similar to the promotion of islands. He states that there is a seeming purity and innocence to the places but that they are highly self-conscious and purposefully constructed places.

The doctrine of islands tries to attest to the idea of the "authentic." David Boyle (2004) proposes that in contemporary society, an authentic brand must be: ethical, natural, honest, simple, unspun, sustainable, beautiful, rooted and human. Islands, and indeed crafts as well (Luckmann, 2015), are often placed in the position of being the "real thing." By checking off all the boxes that Boyle lists, it is evident how those promoting islands and islandness can easily slip into this "brand-speak." There is a cautionary note that must be considered when attempting to be authentic, particularly when calling upon the pastoral in order to be so. Trilling (1971), while discussing the work of Walter Benjamin, points out that being "oldfashion" means being "inauthentic for the present time" (p. 135). There is always the risk that drawing upon notions of pastoralism in order to be authentic might actually lead people in seeing you as inauthentic. This becomes a potential moment of tension for island cultural workers. By drawing upon islands' cultural markers (e.g. in terms of Scotland variously a 'Viking', 'Norse' or indeed 'Celtic' heritage (see Harvey, Jones, McInroy \& Milligan, 2002), they have to demonstrate that their work have value and virtue in contemporary society. By 
either offering an enduring continuity of legacy to past or by offering innovation that is nonetheless contingent on reference to this 'real' culture of past.

Raymond Williams is cautious about the use of "the pastoral." He says that it "often hides the hard truths of commerce behind the veil of decorous sentiment" (1973, p. 54). This is what can happen when the doctrine of the island is focussed on presenting the island as a place of simplicity and where modernity has not reached. Advocating the purely pastoral sentiment means that social and cultural realities are not being dealt with (Adamson, 2007). The carefully constructed veneer of innocence hides hard realities, like inequality, migration and poverty. Baldacchino (2013) makes similar points about the lack of discussion on materiality when studying islands. He reminds island studies scholars, "It is an embodied engagement with materiality that constructs personal and social identity; as much as it is the other way round" (p. 14). Culture is material, and those working on islands as cultural workers must engage with materials and materiality on a number of different levels. The work they do may seem simple, pastoral and old-fashion, but the simple life is never simple minded (MacCarthy, 1981). Our case studies demonstrate this.

Adamson (2007) argues that we should not necessarily do away with the idea of the pastoral. He states, "Yet when the pastoral is not simply a pair of rose-coloured glasses - when it is occupied self-consciously, rather than celebratory or promotional manner - it can be a powerful way of envisioning social and artistic change" (p. 105). Historically, this challenge was taken on by the founders of the Arts and Crafts movement of the $19^{\text {th }}$ century. The likes of John Ruskin and William Morris both advocated a romantic anti-modernism and a revolutionary socialism. Their goal was to promote and provide "good work" in the face of industrialisation and urbanisation. The proponents of the movement saw "the countryside as the site of self-actualizing labour" (Luckman, 2013, p. 49). Good work could only be achieved outside of the cities. In Scotland, there too is a substantial history of arts and crafts being used to inspire good work with the influence of the Glasgow School including most famously Charles Rennie MacIntosh and Margaret MacDonald. As a relatively small nation Scotland was to feel the influence of the Arts and Crafts movement throughout its large rural and remote island areas where artists colonies, crafts workers and home industries were all informed by a flow of ideas back and forth between the urban and the rural, and indeed as Macdonald has noted, remote island space (Carruthers, 2013; Cumming, 2007; MacDonald, 2013; MacDonald \& Coburn, 2007). What does have a tinge of irony is that today good work is said to be almost exclusively found in the cities; that is dominated by metropolitan accounts of art and cultural expression. As alluded to above, Florida and his followers have continuously focussed on the cities. Much of the work in the academic literature on cultural work has been oriented toward the experiences of those in urban areas (Luckman, 2013). Susan Luckman (2013) starts to fill this gap with her study on cultural workers in the English Lake District and Darwin Australia. Our study on cultural workers located on Scottish islands seeks to add to this debate and contribute to this growing body of research.

\section{Methodology}

For this project, we employ a methodology focused on narrative inquiry and analysis. As such, the social world we are investigating is a storied one (Mason \& Dale, 2011), whereby we make sense of our experiences and articulate meaning and motivations through the act of narration. Narratives not only come to tell us about the individual but allow us to understand 
the social, historical and cultural context within which the person lives. As Catherine Kohler Riessman (2004, p. 333) points out, "[narratives] are located in particular times and places, and individuals' narratives about their troubles are works of history as much as they are about individuals, the social spaces [and places] they inhabit, and the societies they live." Narratives therefore are social and culture constructions. They provide use with rich data that illuminates an individual's attempt to make sense of their social place. We use narratives as the base to create an ontological narrative (Harling Stalker, 2009b) or second-order narratives (Elliot, 2005). These are accounts we may construct as researchers to make sense of the social world, and of other people's experiences. These narratives are methods of presenting social and historical knowledge (Elliot, 2005, p. 13).

In this article, we are focussing on the narratives of two cultural workers drawn from a wider sample of our cultural work research interviewees based throughout the Hebrides and Orkney. While these narratives are not meant to be "representative" (in the positivist-sense) of the larger set of interviews we conducted, they are nonetheless illustrative of cultural workers' lives and their work experiences and provide us with vivid accounts. This case-based inquiry will arguably allow for context-rich knowledge and narrative detail that can generate critical insights into "the many-sided, complex, and sometimes conflicting stories" (Flyvberg, 2004, p. 403) told about cultural work on islands. In doing so, the case-based narrative inquiry means that we respect participants as "subjects with both histories and intentions" (Mishler, 1996, p. 80). As Riessman (2008) highlights, case-based narrative inquiry allows us to see how attentions to small details can not only inform us about the individual but also the connection between that individual and the place they live.

Our informants each offered their own accounts of their cultural work experiences of living and working on small off-shore islands. In each case they explained to us their own route to their current working situation, and crucially also their account of coming to be 'on the island' on which they were currently living. Some of our informants had known the island, or related island areas, since birth, perhaps leaving at certain times in their life to undertake work or education, or for other personal reasons. Others were individuals who had each moved to an island; either the one they resided on currently, or in many cases relocated from one island to another again for various reasons including personal attachments to others such as partners or children. Often the move is precipitated by employment opportunities elsewhere, or necessitated by a lack of them where they were although it should be noted that often cultural workers, as with islanders more generally, may well undertake varying degrees of occupational pluralism. As well as employment factors, the availability of appropriate housing was also a key consideration to location and relocation possibilities (as it is in many remote rural areas).

\section{Case studies: island cultural workers Helen and Jennifer}

What follows here are two exemplars of our island interviewees - Helen from Orkney and Jennifer from a Hebridean island - who each demonstrate the negotiation labour involved with both the precarity of cultural work but also of sustaining a livelihood on a small remote island. Each offer an insight via their narratives of the folding together of both event and time (following Adkins, 2013) in accounts of how one comes to 'be' living and working on an island and the 'doing' of the creative labour of cultural work. Of particular focus here are firstly the nature of decisions and resources informing the account of 'being on the island'; secondly we wished to explore the nature of our informants cultural work as a physical and 
material practice but how this might inform and be informed by the island space; lastly, our interest in community and networks encouraged us to explore with our informants how both 'cultural work' and 'island work' interplay in their stories.

For Helen, her route to the island was through being married to her first husband who came to the island for work. They separated eventually but this had been the early catalyst for a move to the Northern islands: "my ex-husband brought us up here. He hated it; I loved it. I stayed." Later with her second husband and family Helen was to live on another island nearby that was her husband's family home - he was 'from there.' Now she and her husband live on the bigger mainland island in the archipelago largely as a result of a job opportunity that was made available to her at a pivotal point in time. It facilitated easier schooling for her children and seemed the "right thing to do" as the previous lifestyle of working in agriculture with relatively limited acreage was proving challenging; at that time there was "just not enough" return from the land to support all the family. She now works largely 'from home' undertaking various craft work from glasswork, beadwork and metal work and has recently set up a small studio at her house - an old residential caravan - out of which she can work but also sell to passing trade. The bulk of Helen's work is sold online, however. Helen spoke at some length about her various selling platforms from Amazon, Ebay and occasionally Etsy. It has been Amazon that has proved the most lucrative for her. This is consistent with what was found in the Craft in an age of change (BOP, 2012) report that found "Makers in Scotland were more likely to use internet selling channels than were makers in the UK as a whole" (p. 80). It is clear from Helen's account that to earn a living from her creative labour of craft she much engages with digital technologies and the online marketplaces of Amazon and other retail platforms. Passing trade on a small island will not sustain a livelihood, although the opportunity to sell to the visiting cruise ship market has been embraced albeit with a realistic eye on the management of time and labour involved in servicing this market. Helen's work is portable enough that she can make while selling from her stall, for example but this is not an option for all crafts people and artists.

When we asked what brought her to the craft work from that earlier island job in agriculture related employment, Helen explained how with a "small bit of cash" that came available she set herself up as self-starter entrepreneur: "I had an idea and I ran with it". But her narrative makes clear that the seeds of both her craft work and her rural 'fit' were sown much earlier. Having been brought up in a coastal yet rural part of Wales, then later having lived for much of her younger years in a very rural English county Helen offered a clear link between where she had come from to where she is now,

... it was very like where I had lived in Wales; I think it was because I was born in a mountain area - right on the coast and the house I spent the first five years of my life, it had the sea on three sides of it and you were above the tree line - big open skies. I just felt comfortable when I landed here. So that's why I came, and I stayed.

So, as important the role had been of her ex-husband initiating a move to Orkney on the basis of his employment, it is clear that the story Helen tells of why she 'landed here' is arguably more meaningfully to do with her own individual reconciliation with an unknown place that 'felt comfortable' to her; that is become quickly 'known'. In this way Helen has taken ownership of a migration story that must negotiate between both individual and shared histories with both 'good' and 'less good' experiences along the way. 
In terms of her journey to craft and her creative and cultural work again there are some pivotal events that are offered for reflection. An early opportunity " to work with her hands", originally with leather for a shoe making firm and the encouragement within that organisation itself to have workers expand and "set up for themselves" had clearly fostered as sense of both interest but also enterprise. To have had such an encouraging environment to 'do' and 'make' handwork such as leatherwork back in her younger years remains an important 'touchstone' for Helen and her capacity to seize opportunities where they are available is all apparent. On moving to the island location Helen recounts how she was already "doing a little bit of jewellery" but once in Orkney it became clear that Orkney had a "substantial existing tradition of silverwork" and Helen enrolled in "very popular evening classes." She learned how to solder and "make things". Again an individual focus is strongly entwined with the framework of existing island events, histories and a sense of collective others.

Jennifer's account also offers a set of recognizable vignettes and metaphors of coming into an island setting from 'outside' and within the story of this locating to the island Jennifer offers both push and pull factors that informed her decision to move from the Scottish mainland to an offshore island on Scotland's west coast,

I was living in Glasgow; I was at college in Glasgow and I was living there for about seven years then I had this job. I was doing conservation work and I was posted here [to the island] doing this thing ... path building ... footpath building up mountains and I was over here a lot and I used to visit here a lot. I've got a friend who used to be a ranger at the castle and ... and then ... I just decided one day (laughs) to move here. I started basket making in Glasgow but there wasn't space. I was sharing with three other people ... I'd been on a few courses and I wanted to get in on that more ... plus, I was fed up with my boss, and I'd split up with my boyfriends (laughs) so lots of reasons (laughs) I just wanted to get away! So I came and I moved to C. originally just north of B. and I lived there for a few years and then I was living in a wooden chalet type of place. It was really two huts - one hut was the living room kitchen and the other hut was the bedroom bathroom and (laughs) I ended up living in the living room and used the bedroom as my workshop when I was there ... yeah.

Here, Jennifer's account demonstrates the various events and factors that combine to inform her narrative of who she came to be on the island but also a sense of her cultural worker identity emerging. At the same time, she negotiated island resource realities, such as available housing and the necessity of appropriate 'workspace'. Jennifer demonstrates that considerable 'push factors' informed a decision to re-locate but so too was the often key connecting factor for many in-migrants of already possessing knowledge of the island place. Social networks are recognised as integral to the process of getting 'into' islands often through work but also family or friends. Asked later in the interview about what had brought Jennifer to the island she offered another related yet different set of references that informed her decision to locate on the islands,

hmmm ... well ... the scenery, obviously. It's beautiful. And just to get away from the city, I think. Just ... a slower pace of life ... 
Asked if this had then been a lifestyle decision to move then, Jennifer responded with a shift to a more defined link to the opportunity the island setting offered her to do her cultural work of basket making,

I could do the basket making a lot easier ... so ... hmmm. I took the decision to become a basket maker even though I wasn't ... I didn't have much experience when I first came.

Jennifer's move to the island in her account is initially suggestive of a 'quick' decision, "I just decided one day (laughs) to move here," but actually as her account reveals this relocation decision was built upon a series of developed engagements with the island as a physical and material place through visiting her friend and through her conservation work quite literally getting to know the island - building paths in all weathers would have exposed both the physical attractions of the space - the island as "beautiful" but also the challenges that poor weather, seasonal employment and remoteness bring including the necessary reliance on ferry transportation, limited services and high living costs of remote island living. Jennifer makes clear that a move to the island offered an opportunity to undertake her basket making as creative labour and type of cultural work. For her this had not been easily facilitated in her urban environment. The connection to a physical place that chimed with the physicality of making her baskets from natural materials is important. Furthermore, the sense in which a narrative for making something from 'nothing' emerges as a metaphor in Jennifer's account is also interesting. The build your own/DIY approach to their own creative labour offers us interesting parallels with islandness as 'labour' but so too the broader enterprise expectations of island communities today, not least through culture (Danson and Burnett, 2014). It is not Richard Florida's creative cities that facilitated the ability to do the cultural work. It was the material opportunities of the island that allowed Jennifer to initiate her move towards craft.

The crafting of a basket where you start with "just a few twigs and sticks" offers an interesting metaphor for the making of a islander identity for in-migrants where again there are limited 'roots' and connections to the place but over time individuals recognise what they have 'worked at': a set of experiences, networks, a laying down of histories and events that becomes woven as an account of their 'island' story that take form but is physical, material and symbolic. The activity of drawing on various sources of cultural reference, as well as the different making practices are to the fore of Helen's account as is the emotional reward from the act of 'making' but so too as we found with many of our informants is the capacity and the competencies to 'adapt', be flexible and to transfer knowledge that can inform and provide a solution to new challenges and situations,

It is the wonderment of being able to make something like a piece ... a strip of wire and make it into to something like that. And use it ... and so many of the ideas overlap. You'll learn something from every other thing that you develop into something else. That ... the wirework ... I used something very similar to that ... when I used to make Corn Dollies in Somerset and I've just transferred it into something else.

As further comment brought forth from our cultural worker case studies was that we were interested in how networks informed our informants' cultural work but also how this in turn expressed a sense of the 'islandness' of their situation. Rural island communities, especially 
remote rural, are predicated on the shared understanding of what might be appreciated as the ebb and flow of proximity whereby successful island community relations often require a 'good balance' of respectful distance and a maintaining of privacy, while simultaneously acknowledging each other as neighbours, family, friends, co-workers and residents. Working at island living is often recognised as demonstrating sufficient engagement with each other as befits the social norm of island etiquette that largely foster or 'oil the wheels' of everyday harmonious social relations. Furthermore, the recognition of where, when and how island residents might display appropriate community spirit and shared support is something that is often developed over time through experience and shaped by a passing of local knowledge of when and how to be involved with who, and in what capacity. This is a highly organic and historically contingent process and yet each island community largely recognises the normative requirement to 'do' this social and emotional island work of 'getting along'. Cultural workers may well work in collective groups and work spaces not least increasingly the urban metropolitan model to encourage, indeed require, creative enterprise to locate within creative hubs or 'clusters'. The perception may well be that rural areas are 'different,' in that individuals seek to be 'away' from others and yet islands consequently are often 'home' to clusters of artists and creatives in key locations. Concentration patterns appear to persist over time in 'pockets' of cultural and artistic activity while neighbouring spaces and indeed other islands may be largely devoid of any cultural work representation.

So, for example Orkney is noted for its creative activity with considerable high profile output from a number of self-employed artists and creative as well as a number of small and medium sized businesses employing several employees. Orkney is home to many different forms of artistic and craft output, many of them making strong association with the 'local' Orkney heritage and through our interviews with several informants in Orkney it is clear that the cultural work community consists of a myriad of interlinked and overlapping networks of association and allegiance with individuals each developing their own negotiated membership to various networks and each providing 'access' to knowledge and resource and identity affirming of one's cultural work identity but also crucially one's 'island worker' status to various effect

Helen networks on the island, for example, with other jewellery workers "a little". While she must move 'off island' via digital technology and participate in online forums with glassworkers from across the UK, (there are very few glassworkers on Orkney), the bigger population of 'local' jewellery workers most especially silver workers on Orkney might suggest not just an opportunity for ongoing networking and connection but also an 'expectation'. Helen, it seems, has worked through various stages of engagement and the ebb and flow of proximities and implied that it was not just important to retain a degree of distance from each other - respectful both in terms of keeping distance and acknowledging individual differences - but essential both for retaining a sense of bounded island self but also for conferring a degree of individual creative difference. The close-proximity of small-island living as well as the likelihood of more overlapping personal and social histories as well as perhaps the need to negotiate around artistic differences is hinted at here from Helen,

We all know who each other is. And I think most of the time we respect each other's differences. And occasionally there will be a reason why we all need to speak to each other but everybody's different and everybody does something completely different. There are very few people that you'd look at and think 'it's something the same'. 
There is a well understood tension between fitting along together within a bounded island space while actively pursuing an individual identity and perhaps no less so as a 'creative' cultural worker who is often highly visible as a representation of what is 'good' about living and working in a small island remote rural setting. Indeed one's capacity to secure an individual commercial vision and success is implicitly suggested here; that is, the cultural work worker project is one that is broadly seen as one that should succeed. Islands as 'good places' to work - a wealth of cultural and environmental 'specialness' - powerfully underpins the island cultural worker trope. In practice, of course, this can vary enormously from individual to individual: and, arguably, from island to island.

\section{Discussion}

For this account we have purposively selected just two individuals from our wider interview sample. Both of these individuals presented themselves as cultural workers - selling and promoting their work as artists and/or craftworkers - each had arguably strongly positioned their art work or craft as central to a sense work identity, not least through an 'online' and wider commercial presence of 'making and selling' in an island setting in Scotland, (c.f. McAuley and Fillis, 2005 for a more general UK focus). Nonetheless, there was considerable variation in each of the narratives around ideas of what cultural aspects inform their work, and how it was expressed. So too was there variation in how their 'work' as a concept informed their artistic and creative identity. Furthermore, in each case we were interested in examining how the idea of things 'cultural' as a wider 'island' field of reference was articulated by our participants both in terms of how each might influence the other, and the idea of 'exchange' and 'negotiation' around claims to their work identity as cultural and also to the sense of how their work articulated with 'islandness'.

By exploring two selected examples of cultural worker narratives we are able to interpret more fully how they each tell 'their story' of becoming and being cultural workers but also as becoming and being islanders. The making of an authentic account in each case is important to note here. Finding a narrative that fits both with accounts that ring 'true' and have validity for oneself is clearly articulated by our interviewees. But so too is a sense that their story is understood as something expressed and shared and therefore consequently is understood as a social narrative of how one might articulate an islander identity, albeit one as an incomer or in-migrant who has 'made their home' on the island and 'found' their place there/here. Therein lies the 'self work' of the cultural worker island resident who must negotiate in their speaking for a range of identity positions and historical, current, personal and local complexities. The making and crafting of an account is itself important to note and we might share with Tim Ingold (2010) his reflections on art as 'making' the usefulness of the praxis of reflection: the act of creating 'back' into the 'things' and materiality of events and materials.

Telling stories of islanderness ${ }^{3}$ and indeed of telling stories of artistic and cultural work identity are active reflections of how we 'make' our islander and working identities into

\footnotetext{
${ }^{3}$ We note that beyond the articulation of islandness as examined by Conkling (2007) and others, we would argue that there is increasingly a positioning- that is a conscious expression of identity - wherein individuals can articulate a recognition and a shared understanding of knowing what it is to be in various terms and contexts an 'islander'. We suggest that, usually, this expression of islanderness is by those island residents that are either
} 
being. Again following Ingold, we note the possibilities of overlaying accounts of art as making but so too 'the labour of making' an islander self that lives and works; that is there is seen to be a recognition of one's crafted identity informed by a series of flows and processes. The practice of both making art but also of 'making home' on an island is a skill of negotiation and evolution. This is done within doctrines that obscure the difficulty of being creative and the material realities of island life.

Each of our interviewees offered to us a set of evolved, generated frames of being in their accounts. In their telling to us each account of their creative identity, their creative work and their expression of 'islander identity' further evolving narratives into an act of making, crafted and brought into being account of one's self and one's practice. So in our narrative of island cultural workers it is possible to infer what Ingold refers to as the textility of making. Where Ingold has referred more fully to materiality and how this has been 'progressively devalued,' we might invite reflection on how the making of islander identity has being arguably limited in its textility; that is the nuances are at risk of being subsumed by certain formed ideas of what might constitute an 'islander' or an 'in-migrant'. Each of our interviewees recognise a set of 'forces' and 'fields' that impact and inform the everyday practice and possibility of both island life and cultural work but each individual has a capacity - resources, knowledge and competencies - to 'draw and thread together to weave' in Ingold's (2010) terms their own "pathways or lines of becoming into the texture of material flows comprising the lifeworld".

In our exploration of islander cultural workers - each in turn engaged with creative labour - we are able to illustrate more fully how cultural workers and the events and practices within which they operate are highly contingent on social context and what Adkins has termed the 'folding together of time and events' (2013, p. 159). Simply, we might suggest that our islander resident cultural workers while all displaying personal narratives unique to each of them nonetheless also display a set of shared understandings around their work that signifies its 'social' context not least aspects of islandness that remain significantly obdurate (e.g. weather, physical travel demands, transportation of goods costs, small population proximities, housing availability, often singular provision of services). Furthermore to follow Adkins (2013, p. 152): "As workers whose work and working lives are characterised by insecurity, discontinuity and informality, and whose working biographies are therefore necessarily broken into fragments, creative labourers can readily be cast as exemplars of the multi-activity paradigm of work." Furthermore we note Adkins' suggestion of the tendency to use creative worker biographies as examples of Sennett's (2006) political economy of insecurity and a global embrace of what might be understood as 'short-termism, detachment and ambivalence' where one's future is largely unpredictable and 'unknowable'. Yet we might offer our informants as examples of creative individuals engaged in cultural work and creative labour who in some respects do evidence some aspects of the precarity and insecurity of work while celebrating aspects of flexibility and 'invention' of one's working identity; that is as an expression of 'self-actualisation', and consequently a 'knowing', particularly in reference to

\footnotetext{
demarcated as in-migrants 'proper' with no prior claim to island 'roots' or family links, or indeed may be 'returnees' who have such links but have lived elsewhere for substantial periods of their lives only to now have settled and 'returned' to the island. An islander identity is something that, like islandness, is shifting, multifarious, and indeed negotiable. For our informants, we argue that a sense of islanderness was itself an expressed performance of identity whereby individuals claimed not just to know or recognise islandness but rather to experience and lay claim to the embodied subjectivity of islanderness.
} 
the islanderness of one's situated identity. In each case the interplay of their 'individualised' experiences with that of the social, historical and materiality of islandness as it informs/forms their personal and working lives is quite apparent and strongly nuanced throughout their narratives. This interplay further entangles the cultural workers' narratives in the prevailing doctrines mentioned earlier.

\section{Conclusion}

By exploring Helen's and Jennifer's narratives we have seen how island cultural workers have to contend with the doctrines of islands and of creativity. We can see at times when these narratives reiterate many of the established discourse: Jennifer's quick response about the island being a place of beauty, or when Helen talks about how with a bit of money you can start to do cultural work. This is all true; however, when given time to reflect upon this, we see that the doctrines can obscure certain realities. Jennifer, as a single woman, does not have the capital to buy property on the beautiful island to have a studio or even a house of her own. Helen talks about how those on the island doing similar work are often guarded and not as open as the doctrines would have one believe.

This research very much engages with the calls to be more critical of notions such as creativity and pastoral. We need to recognise that both these concepts can certainly aid in producing good work, but to use them blithely and uncritically undermines the realities that island cultural workers face. This is why methodologically the use of narratives, and understanding them in relation to 'making,' allows for the tensions between the socio-political doctrine and the lived experience to be teased out.

The recent call to think about the materiality of islands therefore is being heeded. Baldacchino's (2013) argument to understand the connection between culture and material reality allows for a critical dialogue to happen among cultural work scholars and island studies researchers. Often the two are separated, primarily because of an urban / rural divide. However, with work such as this, and that done by Luckman (2013), this divide now becomes part of the discussion rather than maintaining a place-neutral stance.

Finally, this research can provide some useful insights to the development of policies, both those directed at cultural workers and those directed at islands. This serves as a reminder that there are certain lived realities that should be taken into consideration when trying to foster good work on islands. Many of these considerations are not new to those who live on and study islands (e.g. transportation costs, connectivity); however there are realities that are often overlooked due to a perceived neutral stance. Good work can be influenced by gender, class and availability of capital. While not explicitly part of this analysis, these elements can certainly inform both the doctrines of islands and of creativity, while offering future research opportunities in both Scotland and small island communities elsewhere

\section{References}

Adamson, G. (2007). Thinking through craft. Oxford: Berg.

Adkins, L. (2013). Creativity, biography and the time of individualization. In M. Banks, R. Gill and S. Taylor (Eds.), Theorizing cultural work: Labour, continuity and change in the creative industries (pp. 149-159). London: Routledge.

Aston, D. \& C. Noonan (Eds.). (2013). Cultural work and higher education. Basingstoke: Palgrave Macmillan. 
Baldacchino, G. (2005). Islands: objects of representation, Geografiska Annaler, 87B(4), 247251.

Baldacchino, G. (2013). Island landscapes and European culture: an 'island studies' perspective. Journal of Marine and Island Cultures, 2(1), 13-19.

Baldacchino, G. and Kelman, I. (2014). Critiquing the pursuit of island sustainability. Shima: The International Journal of Research into Island Culture, 8(2), 1-20.

Banks, M., R. Gill, R., \& Taylor, S. (Eds.). (2013) Theorizing cultural work: Labour, continuity and change in the cultural and creative industries. London: Routledge.

Becker, H. S. (1982). Art worlds. Berkeley CA: University of California Press.

Bonnar, A. (2014a, October 26). Cultural policies in Scotland. Submission to Smith Commission on Scotland Devolution, 21 ${ }^{\text {st }}$ Century Blog, Retrieved from https://annebonnar.wordpress.com/category/cultural-policies-scotland/

Bonnar, A. (2014b). What does culture mean to you? The practice and process of consultation on cultural policy in Scotland since devolution, Cultural Trends Special Issue: Scottish Cultural Policy, 23(3), 136-147.

BOP Consulting. (2012). Craft in an age of change. Submission to Crafts Council, Creative Scotland, Arts Council of Wales, Craft Northern Ireland. Retrieved from http://wcceurope.org/sites/default/files/Craft_in_an_Age_of_Change.pdf.

Bourdieu, P. (1990). The field of cultural production. Cambridge: Polity Press.

Boyle, D. (2013). Authenticity: Brands, fakes, spin and the lust for real life. London: Flamingo.

Byron, R. (2003). Retrenchment and regeneration in rural Newfoundland. Toronto ON: University of Toronto Press.

Carruthers, V. A. (2013). The arts and crafts movement in Scotland: A history. New Haven CT: Yale University Press.

Conkling, P. (2007). On islanders and islandness. The Geographic Review, 97(2), 191-201.

Connor, B., R. Gill, R., \& Taylor, S. (Eds.). (2015). Gender and creative labour. Oxford: Wiley Blackwell.

Cumming, E. (2007). Hand, heart and soul: The arts and crafts movement in Scotland. Edinburgh: Birlinn.

Danson, M. and Burnett, K. (2014). Enterprise and entrepreneurship on islands, in C. Henry \& G. McElwee (Eds.), Exploring rural enterprise: New perspectives on research, policy and practice (pp. 151-174). Bingley: Emerald.

Elliot, J. (2005). Using narrative in social research: Qualitative and quantitative approaches. London: Sage Publications.Florida, R. (2002). The rise of the creative class: And how it's transforming work, leisure, community and everyday life. New York: Basic Books.

Hall Aitken (2007). Report for Outer Hebrides Migration Study Client: Comhairle nan Eilean Siar, Western Isles Enterprise and Communities Scotland. Hall Aitken, Glasgow. Retrieved from http://www.cnesiar.gov.uk/factfile/population/documents/OHMSStudy.pdf

Harling Stalker, L. (2009a). Self-employed craft production is embedded work. Journal of enterprising communities, people and places in the global economy, 3(4), 415-425.

Harling Stalker, L. (2009b). A tale of two narratives: Ontological and epistemological narratives. Narrative Inquiry, 19(2), 219-232.

Harvey, D.C., Jones, R., McInroy, N., and Milligan, C. (Eds.) (2001). Celtic geographies: Old geographies, new times. London: Routledge. 
Hesmondhalgh, D., and Baker, S. (2011). Creative labour: Media work in three cultural industries. London: Routledge.

Highlands and Islands Enterprise (HIE) (2014). HIE Creative Industries Strategy 2014-2019. Inverness: HIE.

Ingold, T. (2010). The textility of making. Cambridge Journal of Economics, 34(1), 91-102.

Jedrej, M.C., and Nuttall, M. (1996). White settlers: The impact of rural repopulation on Scotland. Luxembourg: Harwood.

Kelman, I. (2007) Sustainable livelihoods from natural heritage on islands. Island Studies Journal, 2(1), 101-114.

Luckman, S. (2012). Locating cultural work: The politics and poetics of rural, regional and remote creativity. Basingstoke: Palgrave Macmillan.

Luckman, S. (2015). Craft and the creative economy. Basingstoke: Palgrave Macmillan.

Macdonald, M. (2013). Five Essays into Highlands Space, at Murdo Macdonald: Interdisciplinary Highland Space, Retrieved from https://murdomacdonald.wordpress.com/2013/05/

Macdonald, M., \& Coburn, G. (2007). An interview with Murdo Macdonald by Georgina Coburn, Northings. Retrieved from http://northings.com/2007/08/16/murdomacdonald/

MacKay Consultants \& McGrath, T. (1991). The economic and social impact of the arts in the Highlands and Islands of Scotland. Inverness: Highlands and Islands Enterprise.

Mason, J. \& Dale, A. (2011). Understanding social research: Thinking creatively about method. Thousand Oaks CA: Sage.

Matarasso, F. (1996). The Social impact of arts programmes. Stroud: Comedia.

McAuley, A., and Fillis, I. (2005). Careers and lifestyles of craft makers in the 21st century. Cultural Trends, 14(2), 139-156.

McRobbie, A. (2016). Be creative: Making a living in the new culture industries. Cambridge: Polity Press.

Millan, A. (2015, November 9). Developing creative talent in the Highlands and Islands. The Herald. Retrieved from http://www.heraldscotland.com/opinion/13953205.print/

Mulholland, N. (2008, October 7). The cultural economy: Old lamps for New Labour? Renewal: A Journal of Social Democracy, 16(2). Retrieved from http://renewal.org.uk/articles/the-cultural-economy.

Myerscough, J. (1988). The economic importance of the arts in Britain. London: Policy Studies Institute.

Myerscough, J. (1995). The economic importance of the arts in Glasgow. London: Policy Studies Institute.

Parr, H. (2013, August 23). Population boom as thousands flock to Scottish islands, The Independent. Retrieved from http://www.independent.co.uk/news/uk/homenews/population-boom-as-thousands-flock-to-scottish-islands-8782849.html

Putz, G. (1984). On islanders. Island Journal, 1, 26-29.

Riessman, C. K. (2008). Narrative methods for the human sciences. Thousand Oaks CA: Sage.

Royle, S.A. (2008). From marginality to resurgence: the case of the Irish islands. Shima: The International Journal of Research into Island Culture, 2(2), 42-55.

Russell, B. (2013, October 23). Remote Scottish islands are 'the best place to live'. Daily Express. Retrieved from http://www.express.co.uk/news/uk/438676/Remote-Scottishislands-are-the-best-place-to-live 
Scottish Development International (SDI, September 3). (2009). TalentScotland: Living and working in the Highlands and Islands of Scotland. Scottish Government initiative with SDI published on YouTube. Retrieved from http://www.hie.co.uk/regionalinformation/living-and-working-in-scotland/

Sennett, R. (2006). The culture of the new capitalism. Castle lecture series in ethics, politics \& economics. New Haven CT: Yale University Press.

Spring, I. (1990). Lost land of dreams: representing St. Kilda. Cultural Studies, 4(2), 156-175.

Steel, T. (1975). The life and death of St. Kilda. London: Fontana.

Toynbee, J. (2013). How special? Cultural work, copyright, politics. In M. Banks, R. Gill \& S. Taylor (Eds.), Theorizing cultural work: Labour, continuity and change in the creative industries (pp. 86-100). London: Routledge.

Trilling, L. (1971). Sincerity and authenticity. Cambridge MA: Harvard University Press.

Urry, J. (1990). The tourist gaze: Leisure and travel in contemporary societies. London: Sage. Williams, R. (1961/2001). The long revolution. Peterborough, ON: Broadview Press.

Williams, R. (1973). The country and the city. Oxford: Oxford University Press.

Williams, R. (1976/2015). Keywords: A vocabulary of culture and society. Oxford: Oxford University Press. 